MIECZYSŁAW MORAWSKI

\title{
Knowledge sharing processes with the participation of key employees
}

Associate Professor Mieczysław Morawski Wroclaw University of Economics, Department of Business Administration

\section{Introduction}

In present conditions competitive advantage is obtained through the ability to create new values. An organization physical property is less important, however, what it knows and is capable of accomplishing in the knowledge-based economy is of much greater significance. Visible assets do not present the object of special interest in a modern organization, but rather its invisible resources including mainly knowledge based on human capital. In consequence, in case of companies subject to strong competition, an appropriate approach to managing people gains special meaning. The best HR practices are always focused on knowledge management. In recent years Knowledge Management has emerged as one of the prime concerns related to human resources management. In HRM context Knowledge Management stands for the creation, distribution and utilization of knowledge in case of both an individual employee and a group, at an organizational level, for the benefit of employees affected by it aiming at their improvement and advancement. The hereby paper discusses the emerging trends in Knowledge Management 
faced by HR area (Martin, Whiting, Jackson 2010). Furthermore, recent research indicates that intellectual assets and resources can be utilised much more efficiently and effectively if organizations apply knowledge management techniques for leveraging their human resources and enhancing their personnel management (Soliman, Spooner 2000). The central concern of human resources management, especially in relation to organizational learning, is both recruitment and retention of valuable employees (Davenport 2000).

The significant problem influencing the effectiveness of innovative processes is the transfer and dissemination of knowledge in a company. One of the challenges - conceptual and practical - is to encourage key employees to share their knowledge (experience, skills, good practices, ideas) with other company workers. Modern human resources management is necessary for this purpose, defined as human capital management and referring to methods of knowledge management. It is particularly important to gain knowledge from the best valued employees presenting core competences. However, for knowledge diffusion to be real company top management has to prepare adequate conditions and initiate application activities in business strategy, in organization culture, organization structure and in ICT technologies. All the listed factors influence the efficiency of knowledge sharing, knowledge transfer and other knowledge management processes (Gurteen 1999; Cabrera A., Cabrera E.F. 2002; Commings 2004). These factors constitute the context of both created and implemented methods in human capital management which encourage for intellectual involvement in company operations (Adel Ismail Al-Alawi, Nayla Yousif Al-Marzooqi, Yasmeen Fraidoon Mohammed 2007).

\section{Research Methods}

The Author accepted the following understanding of due terms in the study which are important from the perspective of conducted research:

1. Key employees - top class specialists constructing the company core and its both intellectual and substantive elite. They constitute the group of workers who have decisive influence on the value of corporation competencies. They provide unique skills, extensive professional contacts, deep and broad experience. Knowledge which they have acquired is not only advanced, but also an innovative and unique one and therefore it is always of highly individual nature. Its abundant and diversified resources result from many years lasting and an ongoing learning process.

17

MIECZYSŁAW MORAWSKI 
2. Knowledge sharing process - an element of a wider category covering knowledge transfer processes. It consists in transferring knowledge during communication processes, it requires cooperation and direct contact. The process of knowledge sharing refers mainly to passing on knowledge based on individual experience, practically tested skills, personal opinions, judgements and values. Knowledge sharing is primarily concerned with tacit knowledge conversion into explicit one. Intense interpersonal contacts, organization enhanced learning processes, team work, etc. are, among others, fundamental for such conversion.

The research was conducted in the years 2011 and 2012 and was based on a sample consisting of 50 enterprises. The target group covered enterprises seated in western and south-western Poland. The two largest groups, comprising the studied sample of enterprises, represent companies included in a broadly understood automotive industry, as well as enterprises functioning in the sector of tourist services. The selection of type of operations performed by these enterprises resulted from the importance of cars and their spare parts manufacturing, as well as tourism and leisure oriented services, for the development of Polish economy and their significant share in GDP (gross domestic product) creation. Additionally, both automotive industry and services in tourism are the example of economic and organizational success. Enterprises representing these sectors earn large income and frequently implement modern technical and managerial solutions.

The survey questionnaire applied in the study included 18 questions divided into 3 thematic blocks: company management, key employee profile and key workers involved in the knowledge sharing process. The questions were mostly of closed type ones. Company owners or top managers were the questionnaire respondents.

\section{Results}

As the answers provided by the respondents (tab.1) confirm flexible work division is typical for the majority of studied enterprises and their employees participate in regular meetings organized by their supervisors. Additionally, the management strategy followed is characterized by employees' active and personal participation in different processes. 
Tab. 1. Characteristics of the surveyed enterprises

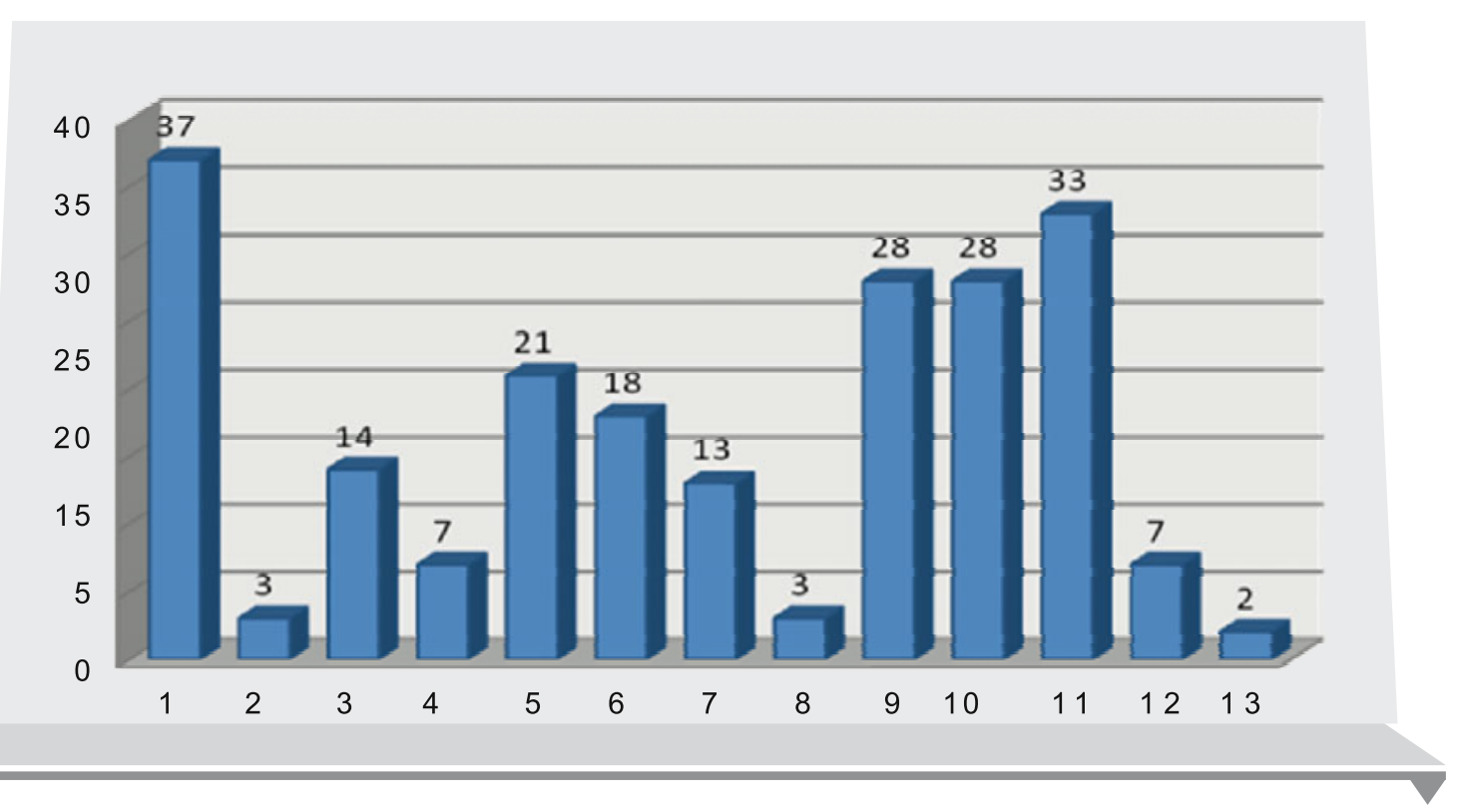

Source: own study based on own research

\begin{tabular}{|c|c|}
\hline $\begin{array}{l}\text { Ordinal } \\
\text { number }\end{array}$ & Qualities \\
\hline 1. & $\begin{array}{l}\text { ongoing and current, objectives focused, work division (tasks, authorization, } \\
\text { responsibility) }\end{array}$ \\
\hline 2. & low level of formality (measured by the number, detailed and rigorous nature of regulations) \\
\hline 3. & $\begin{array}{l}\text { changeable organizational roles (the same roles played by different employees: manager, } \\
\text { specialist, consultant, executor, depending on the task type) }\end{array}$ \\
\hline 4. & $\begin{array}{l}\text { rotation at work positions: employees change their positions depending on specified } \\
\text { rules }\end{array}$ \\
\hline 5. & flexible work time \\
\hline 6. & $\begin{array}{l}\text { flat organization structure (small number of management levels, extensive spread } \\
\text { of management) }\end{array}$ \\
\hline 7. & $\begin{array}{l}\text { low level of decisions centralization (many decisions are made at lower management } \\
\text { levels, lower level management is authorized to solve problems individually) }\end{array}$ \\
\hline 8. & $\begin{array}{l}\text { the majority of workers are appointed for periodical work in different temporary } \\
\text { projects implementation or in expert teams, etc. }\end{array}$ \\
\hline 9. & $\begin{array}{l}\text { the majority of workers participate personally in different processes (contacts with } \\
\text { institutions in their environment, customer service, organization of internal trainings, } \\
\text { negotiations with suppliers, etc. }\end{array}$ \\
\hline
\end{tabular}




\begin{tabular}{c|l}
10. & $\begin{array}{l}\text { supervisors organize regular meetings with employees regarding key issues } \\
\text { (e.g. product advancement, quality improvement) }\end{array}$ \\
\hline 11. & supervisors organize regular meetings with employees regarding current issues and problems \\
\hline 12. & $\begin{array}{l}\text { informal meetings (other than in working hours, workplace, without any initiative } \\
\text { by the supervisor) of employee groups representing a particular company unit and } \\
\text { discussing current professional issues and problems }\end{array}$ \\
\hline 13. & $\begin{array}{l}\text { informal meetings of employee groups representing different organizational units of an } \\
\text { enterprise and discussing current professional issues and problems }\end{array}$ \\
\hline
\end{tabular}

Tab. 2. The requirements necessary for inclusion in the category of key employees

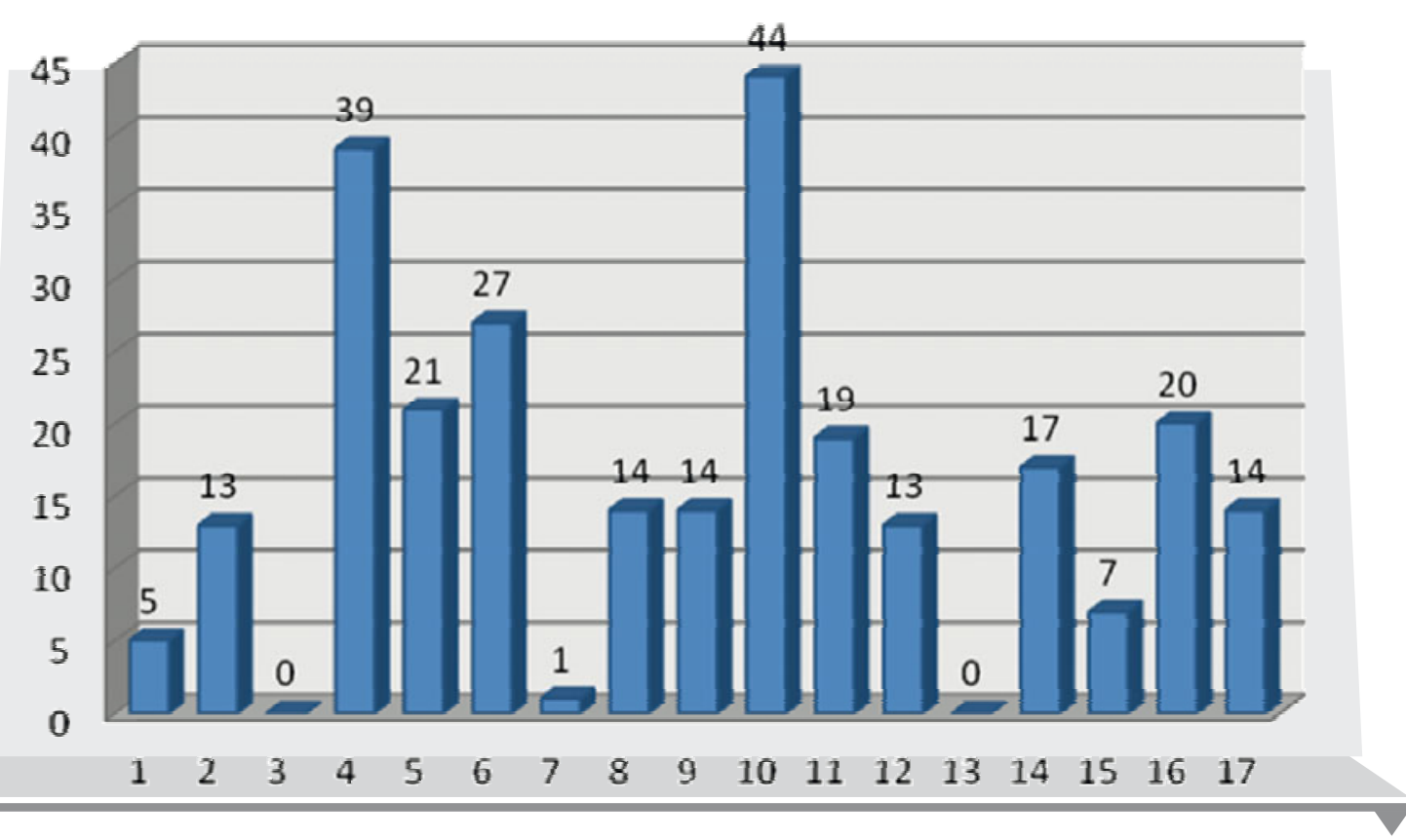

Source: own study based on own research

\begin{tabular}{c|l}
\hline $\begin{array}{c}\text { Ordinal } \\
\text { number }\end{array}$ & \multicolumn{1}{c}{ Qualities } \\
\hline 1. & university graduate \\
\hline 2. & university graduate in the field of study related to the performed job \\
\hline 3. & received many prizes and awards \\
\hline 4. & presents many years of experience in the particular sector of professional activity \\
\hline 5. & $\begin{array}{l}\text { has extensive contacts among suppliers, business partners, other organizations, } \\
\text { specialists, clients, etc }\end{array}$ \\
\hline
\end{tabular}




\begin{tabular}{c|l}
\hline 6. & obtains above average work results \\
\hline 7. & publishes his/her papers in professional journals \\
\hline 8. & $\begin{array}{l}\text { prepares rationalization oriented applications, presents new ideas, registers his/her } \\
\text { patents }\end{array}$ \\
\hline 9. & works in an important, strategic unit/team for the entire enterprise \\
\hline 10. & is a trustworthy person \\
\hline 11. & presents management skills \\
\hline 12. & worked as team leader in the past \\
\hline 13. & currently works as a manager \\
\hline 14. & holds an important position in an enterprise \\
\hline 15. & wins new clients \\
\hline 16. & maintains good relations with important company clients \\
\hline
\end{tabular}

According to respondents' opinions (tab. 2) key employees in their enterprises are mainly characterized by the following qualities: trustworthy, present many years of professional experience, achieve above average work results.

Tab. 3. Ways to emphasize the status of key employees

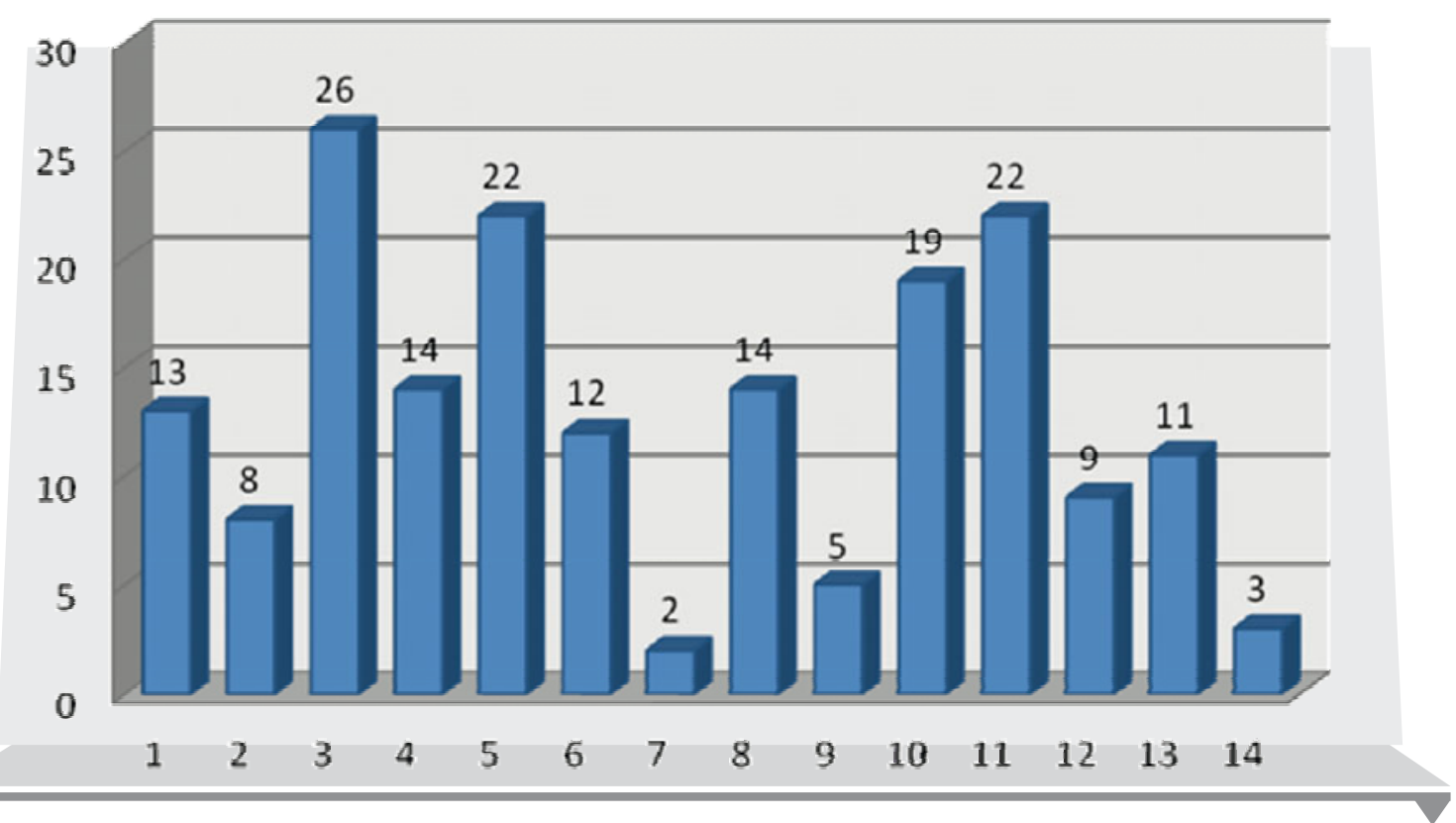

Source: own study based on own research 


\begin{tabular}{|c|c|}
\hline $\begin{array}{l}\text { Ordinal } \\
\text { number }\end{array}$ & Qualities \\
\hline 1. & they are not distinguished in any way comparing to other employees \\
\hline 2. & $\begin{array}{l}\text { they are employed based on individual work contacts (employment agreement, other } \\
\text { forms) }\end{array}$ \\
\hline 3. & they are individually remunerated, according to separate criteria and rules \\
\hline 4. & $\begin{array}{l}\text { they receive additional financial benefits covered by an enterprise (medical, leisure } \\
\text { services, holiday trips, additional insurance, etc. }\end{array}$ \\
\hline 5. & $\begin{array}{l}\text { they have more opportunities of business trips than other employees: conferences, fairs, } \\
\text { exhibitions, shows, etc. }\end{array}$ \\
\hline 6. & $\begin{array}{l}\text { they receive higher than the remaining staff financial resources for the participation in: } \\
\text { trainings, courses, post-graduate studies }\end{array}$ \\
\hline 7. & they participate in company profits based on individual agreements with an enterprise \\
\hline 8. & their professional career path has been planned \\
\hline 9. & $\begin{array}{l}\text { they belong to a special group of workers covered by such programmes as e.g. leaders } \\
\text { creation, talent management, managerial positions successors }\end{array}$ \\
\hline 10. & $\begin{array}{l}\text { they have access to strategic knowledge of an enterprise (technologies, development } \\
\text { plans, technical and construction parameters of products }\end{array}$ \\
\hline 11. & $\begin{array}{l}\text { they are invited to participate in management board, supervisory board and other } \\
\text { company management meetings as consultants, experts, advisors, etc. }\end{array}$ \\
\hline 12. & $\begin{array}{l}\text { they are appointed to work in permanently or temporarily functioning groups of experts } \\
\text { playing the role of company management consultants }\end{array}$ \\
\hline 13. & $\begin{array}{l}\text { they work as managers of specially appointed commissions, teams for solving particular } \\
\text { company problems }\end{array}$ \\
\hline 14. & other ..... \\
\hline
\end{tabular}

Following the respondents' opinions (tab.3), the most important way to emphasize key employees' exceptional status, in their companies, is offering them individual and separately agreed remuneration. Additionally, their special position is also recognized by inviting them to top management team meetings as consultants or experts. Another important factor confirming their special position takes the form of extensive opportunities for participating in business trips to conferences, fairs, exhibitions held for their sector, etc. A group of key workers also has access to enterprises strategic knowledge. 
Tab. 4. Personal incentives that can be attributed to key employees dividing their knowledge to younger and less experienced colleagues in an enterprise

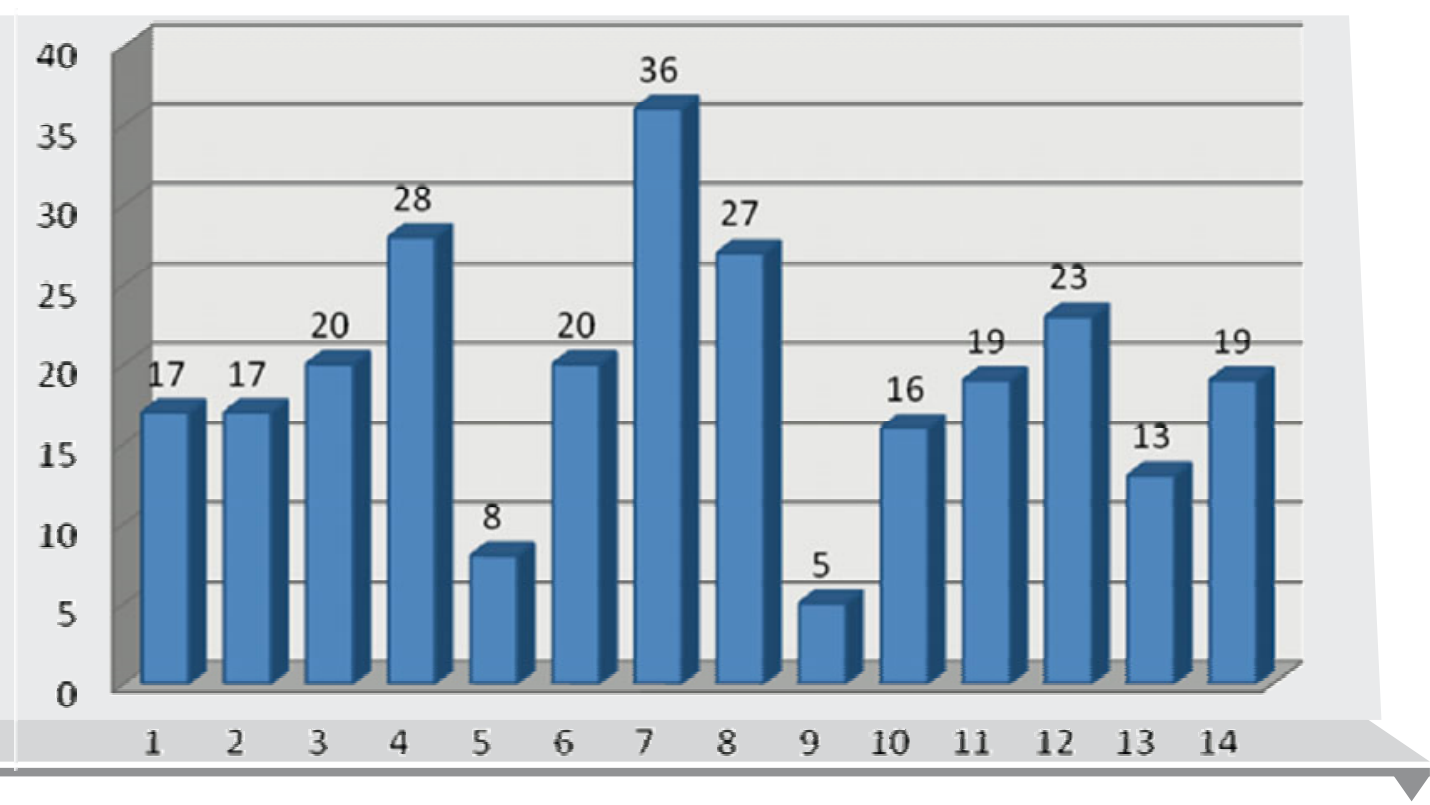

Source: own study based on own research

\begin{tabular}{c|l}
\hline $\begin{array}{c}\text { Ordinal } \\
\text { number }\end{array}$ & \multicolumn{1}{c}{ Incentives } \\
\hline 1. & the desire to receive additional remuneration (or a special bonus) offered by an enterprise \\
\hline 2. & $\begin{array}{l}\text { hoping for promotion (higher periodical assessment) for assistance offered to other } \\
\text { colleagues }\end{array}$ \\
\hline 3. & emphasizing the position of a master, an unquestionable authority in a particular domain \\
\hline 4. & gaining recognition, admiration for the obtained professional knowledge \\
\hline 5. & $\begin{array}{l}\text { imposing an individual point of view, ideas, assessments, observations on other } \\
\text { colleagues }\end{array}$ \\
\hline 7. & concerns related to poorer quality of tasks carried out by less experienced colleagues \\
\hline 8. & focus on higher efficiency of the results planned by the team (entire enterprise) \\
\hline 9. & $\begin{array}{l}\text { the willingness to pay back the resources spent by an enterprise on upgrading individual } \\
\text { qualifications }\end{array}$ \\
\hline 10. & $\begin{array}{l}\text { the sense of strong emotional bond with an enterprise, pride and loyalty towards an } \\
\text { organization }\end{array}$ \\
\hline$\ldots$
\end{tabular}




\begin{tabular}{c|l}
11. & $\begin{array}{l}\text { the sense of obligation and a well-conceived work ethics in a particular profession } \\
\text { (at a given position) }\end{array}$ \\
\hline 12. & $\begin{array}{l}\text { the sense of responsibility for the development of less experienced, younger } \\
\text { colleagues }\end{array}$ \\
\hline 13. & preparing one's successors at a given position (for a particular function) \\
\hline 14. & the desire to pass over one's professional output to others and preserve it in time \\
\hline
\end{tabular}

It turns out, as the respondents' answers illustrate (tab. 4), that the key employees are assigned certain motivating factors confirming great responsibility of this group for the result of company performance. It is also very important for them to win or maintain both recognition and respect of their company colleagues.

Tab. 5 The kinds of motivation incentives that are applied encouraging key employees to share their knowledge with colleagues and the kinds of incentives that should be applied in surveyed enterprises

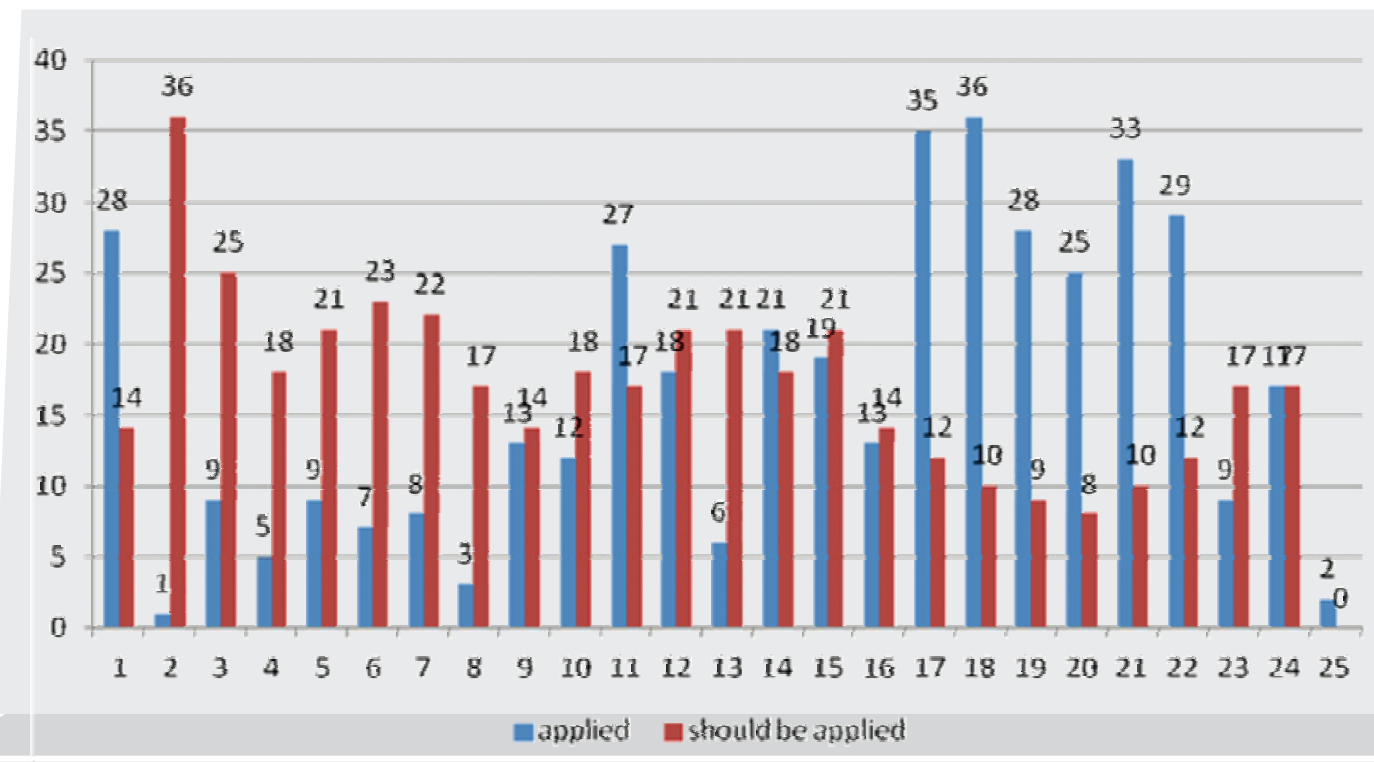

Source: own study based on own research 


\begin{tabular}{|c|c|c|c|}
\hline $\begin{array}{l}\text { Ordinal } \\
\text { number }\end{array}$ & Motivation incentives & $\begin{array}{c}\text { encourag- } \\
\text { ing for } \\
\text { knowledge } \\
\text { sharing } \\
\text { APPLIED }\end{array}$ & $\begin{array}{c}\text { encouraging } \\
\text { for knowledge } \\
\text { sharing } \\
\text { SHOULD BE } \\
\text { APPLIED }\end{array}$ \\
\hline 1. & higher percentage of base salary & & \\
\hline 2. & $\begin{array}{l}\text { special permanent financial remuneration for participating } \\
\text { in the process of co-workers education }\end{array}$ & & \\
\hline 3. & high special bonuses & & \\
\hline 4. & $\begin{array}{l}\text { sharing awards received by co-workers with whom } \\
\text { knowledge was shared }\end{array}$ & & \\
\hline 5. & $\begin{array}{l}\text { sharing awards received by a team made up of employees } \\
\text { with whom knowledge was shared }\end{array}$ & & \\
\hline 6. & $\begin{array}{l}\text { commission for higher knowledge productivity (e.g. } \\
\text { faster knowledge transfer to those who need it) }\end{array}$ & & \\
\hline 7. & $\begin{array}{l}\text { appointing for work in the group of company experts } \\
\text { with higher remuneration to follow }\end{array}$ & & \\
\hline 8. & shares ownership in company equity & & \\
\hline 9. & $\begin{array}{l}\text { additional benefits and perks /privileges, e.g. extra } \\
\text { equipment at workplace/ }\end{array}$ & & \\
\hline 10. & detailed plan of professional development & & \\
\hline 11. & attractive trainings & & \\
\hline 12. & participation in conferences & & \\
\hline 13. & external internships & & \\
\hline 14. & promotion to a higher managerial position & & \\
\hline 15. & possibility of a project team leadership & & \\
\hline 16. & $\begin{array}{l}\text { choice of a new or additional function, organizational } \\
\text { role, e.g. of a mentor }\end{array}$ & & \\
\hline 17. & $\begin{array}{l}\text { higher independence in carrying out the so far performed } \\
\text { tasks }\end{array}$ & & \\
\hline 18. & employment contract for an indefinite period & & \\
\hline 19. & flexible work time & & \\
\hline 20. & unlimited access to company database & & \\
\hline 21. & $\begin{array}{l}\text { unlimited access to supervisors including top company } \\
\text { management }\end{array}$ & & \\
\hline
\end{tabular}




\begin{tabular}{c|l|l|l}
22. & $\begin{array}{l}\text { influence on some personnel decisions, e.g. regarding new } \\
\text { staff employment at vacant positions, types of trainings } \\
\text { for workers }\end{array}$ & $\begin{array}{l} \\
\text { particular successor }\end{array}$ & \\
\hline 24. & influence on the talent management programme & & \\
\hline 25. & other ............... & & \\
\hline
\end{tabular}

In general, the respondents indicate (tab.5) that determinants encouraging for knowledge sharing, in their enterprise, represent operational factors related to more extensive independence in carrying out tasks, flexible work time or unlimited access to information and supervisors, also these at the top management positions. The sense of enjoying professional stability is also highly valued by key employees, i.e.: permanent work agreement, high remuneration. On the other hand, the need for applying adequate financial solutions is often mentioned. The respondents probably assume that it could function as an additional factor to strengthen motivation for knowledge sharing.

\section{Discussion}

Knowledge represents a dynamic rather than static category. If it is left to itself without any imposed discipline it, just like water or air, spreads freely in a given space, both inside and outside an enterprise. If it is assumed that knowledge results from cognitive processes initiated and modelled by observing environment, experimenting, acquiring information, obtaining skills, participation in the actually occurring processes - then the majority of these activities require interpersonal contacts. In the course of social interactions with another person or a group of people an exchange of thoughts takes place, as well as the confrontation of opinions, enriching one's own professional position, creative development of ideas, new proposals and suggestions are offered, which often happens as the result of a different outlook taken at a given problem by a person after he/she has acquired new knowledge. The significance of social contacts network keeps growing in the circumstances in which intense, frequent, indirect, informal communication between specialists is important owing to unusual, complex, multi-layered problems, unique projects, radical changes they experience in their professional operations. 
Mutual consultations, discussions, disputes, exchange of information, knowledge sharing turn out indispensable.

It is necessary to have an overall idea of knowledge oriented enterprise management. It is required to establish strong correlation between company values ingrained in its organizational culture, its vision and strategy, its business model and personnel policy, especially regarding these key employees attracting and retaining who create its competitive advantage. It is indispensable to combine the concept and the implementation of personnel functions with the selected components (processes, tools) for knowledge management. Both human resources management and knowledge management have to be directly related to an overall business management model in a particular company. It is necessary to specify, at the strategic level of an enterprise management, the substantive guidelines for key employees management system construction. The underlying guidelines are as follows:

1. The identification of basic values featuring a professional company and ingrained in the concept of an intelligent organization. Professionalism is of fundamental importance as the basic imperative influencing attitudes presented towards supervisors and co-workers and manifesting itself in competent, rational, thought over and logical activities. Autotelic values are represented by the high level of professional competencies, creativity in thinking and functioning, individual approach to an employee, expressing one's own opinion openly regarding the company or the team, continuous experimenting, good interpersonal relations emphasizing the significance of a master - learner relation.

2. The identification of a vision, mission and strategic goals focused on competitive advantage construction based on intellectual capital quality. Its consequence is shown in the form of emphasis placed on attracting, developing and retaining best personnel in the company.

3. Defining key competencies in an organization which ensure its competitive position at a given market. It refers to certain unique skills which allow an enterprise for added value creation, as perceived by its clients, which outweighs advantages offered by market competitors.

4. Distinguishing key knowledge focused employees. It has to be clearly specified which employees and at which positions present competencies which are in what respect crucial for an enterprise competitive position construction (e.g. unique education, intellectual predispositions for creative performance, entrepreneurial attitudes and behaviour, extensive business contacts). The remaining knowledge oriented workers, based on tests in professional qualities, the presented developmental potential, opinions 
of supervisors and current work results, should be divided and qualified into different categories of employees.

5. Individual strategy preparation for key employees. The most important choices to make: signing agreements which guarantee employment stabilization and opportunities for professional development, providing comfortable working conditions, offering capital partnership. Particular solutions referring to key employees can follow the suggestions presented below:

6. Company environment monitoring by means of formal relations (personal consultancy agencies, universities, research and development institutes) and informal ones (distinctive scientists, patent authors, inventors, professional experts) in order to attract the best candidates from the environment.

7. Ongoing monitoring and development of company employees presenting the highest potential and performance by applying talent management or leader creation programmes, by the establishment of suggestions offering systems.

8. Flexible selection of human resources management methods divided into the leading and supportive ones, depending on the preferred development directions and company expansion. The situation may prefer new knowledge creation methods (technologies, products), the existing solutions implementation in new applications, gaining knowledge from external sources, concentrating knowledge in teams, sharing knowledge between functional areas, etc.

9. Constructing tools for the purposes of knowledge intensification and dissemination in an enterprise: information techniques, access to data bases or the topography of office rooms.

\section{Conclusions}

The problems of knowledge sharing by key employees, their inner incentives, as well as the underlying motivating factors created by enterprise management, require an ongoing and in-depth exploration. However, it seems that the respondents do not present a clearly defined opinion regarding factors which facilitate an effective knowledge sharing process. The problem, therefore, has to be approached in a complex manner. It is absolutely obvious that in cannot be studied as a unilateral case by pointing to the decisive importance of just one group of factors. 


\section{Summary}

Knowledge sharing processes with the participation of key employees

The fundamental of the most important problems of human capital management, especially in relation to knowledge management is theoretical research and application verification conditions, motives and methods to encourage key employees of companies to communicate the knowledge of low-skilled workers. Key personnel represent top-class professionals. They include top managers, senior executives of long-term employment in a company and specialists presenting unique knowledge and skills. The Author presents research findings based on questionnaire surveys made up of a sample consisting of fifty companies operating in Poland.

Keywords: key employee, knowledge sharing, key employees motivating, human capital.

\section{Streszczenie}

\section{Procesy dzielenia się wiedzą $\mathrm{z}$ udziałem pracowników kluczowych}

Podstawowym wśród najważniejszych problemów zarządzania kapitałem ludzkim, w szczególności w relacjach z zarządzaniem wiedzą są badania teoretyczne i ich aplikacyjna weryfikacja pod kątem warunków, motywów i metod skłaniających pracowników kluczowych przedsiębiorstw do przekazywania wiedzy pracownikom o niskich kwalifikacjach. Kluczowy personel to najwyższej klasy profesjonaliści. Zaliczamy do nich najwyższy szczebel zarządzania, kadra kierownicza z długoletnim okresem zatrudnienia $\mathrm{w}$ firmie, specjaliści posiadający unikalną wiedzę i umiejętności. Autor prezentuje wyniki badań oparte na badaniach ankietowych próby pięćdziesięciu przedsiębiorstw działających w Polsce.

\section{Słowa}

kluczowe: pracownik kluczowy, dzielenie się wiedza, motywowanie pracowników kluczowych, kapitat ludzki. 


\section{References}

1. Adel Ismail Al-Alawi, Nayla Yousif Al-Marzooqi, Yasmeen Fraidoon Mohammed (2007), Organizational culture and knowledge sharing: critical success factors, "Journal of Knowledge Management", Vol. 11 Iss: 2, pp. 22- 42

2. Cabrera, A.; Cabrera E. F. (2002), Knowledge-sharing Dilemmas, „Organization Studies” 23 (5), pp. 687-710.

3. Commings J. N.(2004), Works Groups, Structural Diversity and Knowledge Sharing in a Global Organization, "Management Science”, Vol. 50, Iss: 3, pp. 352-364.

4. Davenport T. (2000), Human Capital: What it is and why people invest in it. San Francisco: Jossey-Bass.

5. Gurteen D. (1999), Creating a Knowledge Sharing Culture, „Knowledge Management Magazine", Vol. 6 Iss: 5, February.

6. Martin M., Whiting F., Jackson T. (2010), Human Resource Practice, Fifth ed. London: Chartered Institute of Personnel and Development.

7. Soliman F., Spooner K. (2000), Strategies for implementing knowledge management: role of human resources management, "Journal of Knowledge Management", Vol. 4 Iss: 4, pp. 337-345. 